\title{
PERILAKU MENGONSUMSI MAKANAN BERGIZI SELAMA PANDEMIC COVID-19 PADA MASYARAKAT SULAWESI TENGGARA
}

\author{
Lisnawaty ${ }^{1}$ Reski Eka Sakti Ocktaviani ${ }^{2}$ Renni Meliahsari ${ }^{3}$ Aldian $^{4}$ Nur Haerati ${ }^{5}$ \\ 1,2,3,4,5 Fakultas Kesehatan Masyarakat, Universitas Halu Oleo, Kendari \\ ${ }^{1}$ lisnawaty@uho.ac.id ${ }^{2}$ resoctaviani@gmail.com ${ }^{3}$ renni.meliahsari@gmail.com ${ }^{4}$ aldianbara31@gmail.com \\ ${ }^{5}$ nurhaeratia@gmail.com ${ }^{5}$
}

\begin{abstract}
Abstrak
Wabah corona virus (Covid-19) merupakan masalah yang terjadi hampir di semua belahan dunia, yang terjadi di akhir tahun 2019 dan sampai saat ini angka kejadiannya masih cukup tinggi termasuk di Indonesia. Dalam mencegah penularan Covid-19, WHO dan Kementerian Kesehatan menghimbau masyarakat untuk menggunakan masker, rajin mencuci tangan, menjaga jarak serta mengonsumsi makanan sehat dan bergizi. Gizi yang cukup sangat diperlukan dalam mempertahankan sistem kekebalan tubuh. Memilih asupan makanan bergizi seimbang pada masa pandemic Covid-19 sekarang ini salah satu cara agar daya tahan tubuh tetap prima. Dampak dari Covid-19 juga mempengaruhi psikologi seseorang dalam pemilihan makanan dan perubahan pola makan. Penelitian ini bertujuan untuk menganalisis perilaku konsumsi makanan pada masyarakat Kabupaten Muna selama pandemic Covid-19, dengan menggunakan rancangan cross sectional study. Sampel dalam penelitian ini adalah semua responden yang mengisi lembar kuesioner secara online yakni sebanyak 701 orang responden. Berdasarkan hasil penelitian didapatkan bahwa pengetahuan ( $p_{\text {value }}=0,673$ ) tidak mempunyai hubungan terhadap perilaku konsumsi. Sikap $\left(P_{\text {value }}=0,000\right)$ dan tindakan $\left(p_{\text {value }}=0,000\right)$ mempunyai hubungan terhadap perilaku konsumsi. Kemudian dilanjutkan uji regresi linear sederhana, didapatkan nilai nilai $R$ Square $\left(R^{2}\right)=0,215$, artinya bahwa sikap dan tindakan memiliki pengaruh sebesar $21,5 \%$ terhadap perilaku konsumsi makanan responden selama pandemic Covid-19 sedangkan 78,5\% dipengaruhi oleh variabel lain. Dari hasil penelitian maka dapat disimpulkan bahwa pengetahuan dan sikap tidak berhubungan terhadap perilaku konsumsi makanan bergizi, sedangkan tindakan mempunyai hubungan signifikan dan pengaruh terhadap konsumsi makanan bergizi masyarakat Kabupaten Muna selama Covid-19.
\end{abstract}

Kata kunci: Covid-19; perilaku; makan bergizi

\begin{abstract}
The corona virus (Covid-19) is a problem in nearly all parts of the world, which spread at the end of 2019 and until now the incidence is still quite high, including in Indonesia. WHO and the Ministry of Health urge people to use masks, wash their hands diligently, keep their distance, consume healthy and nutritious food. Adequate nutrition is needed in maintaining the immune system. Choosing a balanced nutritious food intake during the Covid-19 pandemic is one way that the immune system is maintained. The impact of Covid-19 also affects person's psychology in choosing food and changing diet. This study aims to analyze the food consumption behavior of the people of Muna Regency during the Covid-19 pandemic by using a cross-sectional study. The sample in this research are people who responded to an online questionnaire that as many as 701 respondents. The research results, founded that knowledge $(p$-value $=0.673)$ had no relationship to consumption behavior. Attitude $(p$-value $=0.000$ ) and action has relation ( $p$ value $=0.000$ ) with consumption behavior. The result of refression test, value of $R^{2}=0.254$. The attitude dan action has an effect of $21.5 \%$ on the respondent's food consumption behavior during the Covid-19 pandemic while $74.6 \%$ is influenced by other variables. The results of the study, concluded that knowledge and attitudes are not related to the behavior of consuming nutritious food, while action has a significant relationship and influence on the consumption of nutritious food for the people of Muna Regency during Covid-19.
\end{abstract}

Keywords: Covid-19; behavior; eat nutritious 


\section{PENDAHULUAN}

Pada awal tahun 2020 dunia dikejutkan dengan wabah virus corona (Covid-19) yang menginfeksi hampir seluruh negara di dunia dan sejak Januari WHO menyatakan dunia masuk ke dalam darurat global terkait virus ini dan menjadi masalah kesehatan masyarakat yang serius ${ }^{1}$.

Kebutuhan energi, makronutrien, mikronutrien, cairan, dan zat-zat gizi yang bisa meningkatkan sistem immuno modulator, anti inflamasi, anti oksidan dan probiotik menjadi acuan dalam penyusunan protokol terapi gizi pada pasien Covid-192.

Meningkatkan daya tahan tubuh adalah salah satu kunci untuk mencegah penularan virus Covid19. Mengonsumsi makanan bergizi seimbang merupakan salah satu cara agar daya tahan tubuh tetap prima. Kecukupan gizi terutama vitamin dan mineral sangat diperlukan dalam mempertahankan sistem kekebalan tubuh yang optimal ${ }^{3}$.

Menjaga pola makan yang baik dan sehat sangat penting selama pandemi Covid-19. Walaupun tidak ada makanan atau suplemen makanan yang dapat mencegah penularan virus Covid-19, mengubah pola makan dengan mengonsumsi makanan bergizi seimbang yang sehat dan sangat penting dalam meningkatkan sistem kekebalan tubuh yang baik ${ }^{2}$.

Kemenkes RI merekomendasikan makan makanan bergizi dan seimbang sangat penting dalam membentuk kekebalan tubuh sehinga dapat melindungi tubuh dari infeksi virus serta memberikan perlindungan ekstra bagi tubuh. Makanan seimbang terdiri dari makanan pokok (karbohidrat), lauk pauk sebagai sumber protein hewani dan nabati, serta sayur dan buah sebagai sumber vitamin dan mineral ${ }^{3}$.

Pengetahuan masyarakat dalam memilih pangan yang cukup dan seimbang untuk individu dan keluarga sangat dipengaruhi oleh tingkat pendidikan, sosial ekonomi dan budaya. Pada keluarga miskin umumnya, karena akses pendidikan, pelayanan kesehatan dan daya beli pangan yang rendah, menyebabkan timbul masalah kurang gizi. Pengetahuan keluarga tentang penanganan pangan yang aman juga turut berkontribusi dalam menentukan status gizi keluarga ${ }^{4}$.

Perilaku konsumsi makanan seseorang dipengaruhi oleh wawasan dan cara pandang serta faktor lain yang mempengaruhi tindakan seseorang. Pengetahuan gizi merupakan landasan yang penting dalam menentukan konsumsi makanan ${ }^{5}$. Memilih asupan makanan saat pandemik Covid-19 penting untuk mengutamakan jenis makanan yang dapat meningkatkan daya tahan tubuh.
Tujuan penelitian ini adalah menganalisis perilaku (pengetahuan, sikap dan tindakan) terkait konsumsi makanan pada masyarakat Kabupaten Muna selama pandemic Covid-19.

\section{METODE}

Penelitian ini adalah penelitian analitik observasional dengan rancangan cross sectional study. Sampel dalam penelitian ini adalah semua responden yang mengisi kuesioner (google form) secara online dan berdomisili di Kabupaten Muna. Penelitian ini akan menganalisis perilaku yang mencakup pengetahuan, sikap dan tindakan masyarakat Kabupaten Muna dalam mengonsumsi makanan yang sehat dan bergizi selama pandemic Covid-19.

\section{HASIL DAN DISKUSI}

\section{Pengetahuan}

Pengetahuan merupakan suatu kemampuan untuk memahami suatu objek dengan menggunakan alat-alat panca indera manusia yang diperoleh dari berbagai sumber diantaranya melalui membaca, pendidikan, penyuluhan, dan media massa ${ }^{6}$. Distribusi pengetahuan terhadap perilaku konsumsi makanan selama pandemic Covid-19, dapat dilihat pada tabel berikut:

Tabel 1. Hubungan pengetahuan terhadap perilaku konsumsi makanan selama pandemi Covid-19

\begin{tabular}{lccccccc}
\hline & \multicolumn{4}{c}{ Perilaku } & \multirow{2}{*}{ Total } & \multirow{2}{*}{ Nilai P } \\
\cline { 2 - 6 } Pengetahuan & \multicolumn{2}{c}{ Kurang } & \multicolumn{2}{c}{ Cukup } & & & \\
\cline { 2 - 6 } & $\mathrm{n}$ & $\%$ & $\mathrm{n}$ & $\%$ & $\mathrm{n}$ & $\%$ & \\
\hline Kurang & 6 & 27,3 & 16 & 72,7 & 22 & 100 & \\
Cukup & 214 & 31,5 & 465 & 68,5 & 679 & 100 & 0,673 \\
\hline \multicolumn{1}{c}{ Total } & 220 & 31,4 & 481 & 68,6 & 701 & 100 & \\
\hline
\end{tabular}

Berdasarkan hasil penelitian didapatkan bahwa 679 responden yang memiliki pengetahuan cukup baik terkait makanan sehat, bergizi dan seimbang, hal ini didukung oleh banyaknya informasi yang telah didapatkan oleh responden terkait pentingnya mengonsumsi makanan sehat dan bergizi selama pandemic Covid-19 untuk menjaga daya tahan tubuh.

Hasil penelitian juga menunjukkan bahwa dari 679 responden yang berpengetahuan cukup, terdapat 214 responden yang memiliki perilaku kurang baik dalam konsumsi makanannya, hal ini disebabkan karena ketidakmampuan masyarakat dalam menyediakan dan mengonsumsi makanan yang beragam dan cukup gizi, karena jika dilihat dari pendapatan masyarakat masih banyak yang memiliki pendapatan rendah. Selain itu juga dipengaruhi karena banyak masyarakat yang 
memiliki pekerjaan tidak tetap dan kondisi tersebut semakin kurang baik saat pandemic Covid-19 karena beberapa masyarakat akhirnya tidak bisa bekerja.

Hasil uji chi-squre menunjukkan bahwa tidak ada hubungan antara pengetahuan terhadap perilaku konsumsi gizi selama pandemi Covid-19. Hal ini sejalan dengan penelitian sebelumnya yang menemukan bahwa tidak ada hubungan antara pengetahuan gizi dengan asupan energi dan zat gizi makro ${ }^{7}$. Hal ini juga didukung oleh hasil penelitian lain yang menemukan bahwa tidak ada hubungan bermakna antara pola konsumsi dengan pengetahuan tentang gizi ${ }^{8}$.

Kurangnya pengetahuan tentang gizi seimbang dan sikap dalam memilih makanan akan berpengaruh terhadap perilaku dalam memilih makanan, yang nanntinya akan berdampak pada status gizi. Semakin tinggi tingkat pengetahuan gizi seseorang diharapkan semakin baik pula keadaan gizinya. Akan tetapi, pengetahuan gizi yang dimiliki seseorang belum tentu dapat mengubah kebiasaan makannya, dimana mereka memiliki pemahaman terkait asupan nutrisi yang diperlukan oleh tubuh tetapi tidak mengaplikasikan pengetahuan gizi tersebut dalam kehidupan sehari-harinya. Oleh sebab itu, pengetahuan gizi yang baik juga harus disertai dengan praktik atau perilaku dalam kehidupan sehari-hari ${ }^{9}$.

\section{Sikap}

Banyak faktor yang mempengaruhi sikap seseorang terhadap konsumsi makanan bergizi. Faktor-faktor yang dapat mempengaruhi sikap, yaitu pengalaman pribadi, pengaruh orang lain yang dianggap penting, pengaruh budaya, media massa, lembaga pendididkan dan lembaga agama yang dapat mempengaruhi pengetahuan seseorang, dan faktor emosional ${ }^{10}$. Distribusi sikap responden terhadap perilaku konsumsi makanan bergizi selama pandemic Covid-19 dapat dilihat pada tabel berikut:

Tabel 2. Hubungan sikap terhadap perilaku konsumsi makanan selama pandemic Covid-19

\begin{tabular}{cccccccc}
\hline \multirow{3}{*}{ Sikap } & \multicolumn{4}{c}{ Perilaku } & \multirow{2}{*}{ Total } & \multirow{2}{*}{ Nilai P } \\
\cline { 2 - 6 } & \multicolumn{2}{c}{ Kurang } & \multicolumn{2}{c}{ Cukup } & & \\
\cline { 2 - 7 } & $\mathrm{n}$ & $\%$ & $\mathrm{n}$ & $\%$ & $\mathrm{n}$ & $\%$ & \\
\hline Kurang & 90 & 43,1 & 199 & 56,9 & 209 & 100 & \\
Cukup & 130 & 26,3 & 262 & 73,6 & 492 & 100 & 0,000 \\
\hline Total & 220 & 31,4 & 481 & 68,6 & 701 & 100 & \\
\hline
\end{tabular}

Hasil penelitian ini menunjukkan bahwa ratarata responden menjawab sangat setuju dan setuju pada pertanyaan konsumsi makanan bergizi secara cukup dan seimbang dapat meningkatkan daya tahan tubuh. Begitupun dengan pertanyaan manfaat vitamin pada buah dan sayur, rata-rata responden menjawab sangat setuju dan setuju.
Olehnya itu pada hasil SPSS dapat dilihat bahwa sebagian besar responden atau 410 responden yang memiliki sikap yang positif terhadap konsumsi makanan bergizi selama pandemic Covid-19. Hal ini dapat dipengaruhi oleh pengetahuan yang dimiliki responden, selain itu faktor lain yang dapat mempengaruhi sikap responden adalah faktor kebiasaan makan keluarga, lingkungan, kebudayaan dan informasi/referensi yang didapatkan terkait konsumsi makanan bergizi khususnya selama pandemic Covid-19. Sikap mengandung komponen efektif, sikap terbentuk dari pengalaman seseorang, bertambah dan berkembang dalam psikis yang lain, merupakan proses internal, melibatkan keseluruhan pribadi dalam menanggapi objek pada suatu situasi. Sikap tentang makanan dapat dipengaruhi oleh pengalaman pribadi yang telah ada dan yang kita alami sehingga membentuk dan mempengaruhi anak dalam memilih makanan.

Dari hasil penelitian juga diketahui bahwa dari 492 responden yang memiliki sikap cukup, namun terdapat 130 responden yang perilakunya kurang terhadap konsumsi makanan bergizi. Hal ini juga dipengaruhi karena faktor ekonomi masyarakat yang rendah sehingga menyebabkan ketidakmampuan mereka dalam menyediakan makanan yang bergizi pada tingkat rumah tangga. Sikap terhadap gizi merupakan tahapan lebih lanjut dari pengetahuan gizi. Seseorang yang berpengetahuan gizi baik akan mengembangkan sikap gizi yang baik ${ }^{5}$.

Hasil analisis uji chi-squre menunjukkan bahwa ada hubungan antara sikap terhadap perilaku konsumsi gizi selama pandemic Covid-19 dengan nilai $p$ value 0,000 . Penelitian ini sejalan dengan penelitian sebelumnya yang menyatakan bahwa sikap berhubungan signifikan dengan praktik pemenuhan gizi keluarga ${ }^{11}$.

Berdasarkan hasil penelitian juga dapat dilihat bahwa yang memiliki sikap cukup terhadap konsumsi makanan bergizi selama pandemic Covid19 cenderung mengonsumsi makanan yang bergizi. $\mathrm{Hal}$ ini sejalan dengan teori yang mengatakan bahwa tingkat pengetahuan gizi seseorang berpengaruh terhadap sikap dan perilaku dalam memilih makanan yang menentukan mudah tidaknya seseorang memahami manfaat kandungan gizi dari makanan yang dikonsumsi ${ }^{12}$. Berdasarkan teori Green, sikap merupakan faktor yang mempermudah terjadinya sutu perilaku' ${ }^{6}$.

Sikap manusia terhadap makanan dibentuk sejak masa anak-anak dan dipengaruhi oleh pengalaman dan respon yang diperlihatkan oleh orang lain terhadap makanan. Pengalaman yang diperoleh ada yang dirasa menyenangkan atau sebaliknya sehingga setiap orang mempunyai sikap 
suka atau tidak suka (like or dislike) terhadap makanan. Sikap merupakan predisposisi suatu tindakan. Sikap bukan merupakan reaksi terbuka atau tingkah laku yang terbuka ${ }^{13}$.

\section{Tindakan}

Tindakan merupakan pelaksanaan atau mempraktikkan apa yang diketahui dan disikapinya ${ }^{6}$. Dalam penelitian ini yang dimaksud dengan tindakan adalah tindakan seseorang dalam memilih dan mengonsumsi makanan bergizi sebagai upaya untuk menjaga kesehatannya selama pandemic Covid-19. Distribusi responden berdasarkan tindakan dalam mengonsumsi makanan bergizi selama pandemic Covid-19 dapat dilihat pada tabel berikut:

Tabel 3. Hubungan tindakan terhadap perilaku konsumsi makanan selama pandemic Covid-19

\begin{tabular}{cccccccc}
\hline \multirow{2}{*}{ Tindakan } & \multicolumn{4}{c}{ Perilaku } & \multicolumn{2}{c}{ Total } & \multirow{2}{*}{ Nilai P } \\
\cline { 2 - 6 } & \multicolumn{2}{c}{ Kurang } & \multicolumn{2}{c}{ Cukup } & & & \\
\cline { 2 - 7 } & $\mathrm{n}$ & $\%$ & $\mathrm{n}$ & $\%$ & $\mathrm{n}$ & $\%$ & \\
\hline Kurang & 119 & 63 & 70 & 37, & 189 & 100 & \\
Cukup & 101 & 19,7 & 411 & 80,3 & 512 & 100 & 0,000 \\
\hline \multicolumn{1}{c}{ Total } & 220 & 31,4 & 481 & 68,6 & 701 & 100 & \\
\hline
\end{tabular}

Hasil penelitian menunjukkan bahwa dari 701 responden, yang memiliki tindakan cukup sebanyak 512 responden dan 411 diantaranya juga memiliki perilaku yang cukup dalam mengonsumsi makan bergizi selama pandemic Covid-19. Dari penelitian ini dapat disimpulkan bahwa tindakan adalah wujud nyata dari perilaku. Seseorang yang memiliki pengetahuan dan sikap yang baik belum tentu berperilaku yang baik karena tentunya banyak faktor yang dapat mempengaruhinya. Namun, jika seseorang melakukan tindakan yang baik (mengonsumsi makanan bergizi) maka dapat dikatakan bahwa ia mempunyai perilaku yang baik terhadap konsumsi makanan yang bergizi selama pandemic Covid-19.

Tindakan dalam mengonsumsi makanan bergizi yang dimaksud dalam penelitian ini adalah mengacu pada standar yang ditetapkan oleh Kementerian Kesehatan yakni pedoman umum gizi seimbang (PUGS). Dimana mencakup mengonsumsi air putih kurang lebih 8 gelas/hari, mengonsumsi buah-buahan kurang lebih 150-250 g atau setara dengan 3 buah pisang atau jeruk, mengonsumsi sayur-sayuran kurang lebih 250-350 g atau setara dengan 2 1/2 gelas sayur, mengonsumsi makanan pokok atau sumber karbohidrat lebih dari 6-9 sendok makan atau setara dengan satu mangkok kecil, serta mengonsumsi lauk pauk sebanyak lebih dari 2-4 porsi yang terdiri dari lauk pauk hewani dan nabati ${ }^{14}$. Tindakan atau praktik yang dimaksud dalam penelitian ini adalah suatu tindakan berkaitan dengan konsumsi makanan seimbang yang diterapkan dalam kehidupan sehari-hari.
Hasil analisis uji chi-squre menunjukkan bahwa ada hubungan antara tindakan terhadap perilaku konsumsi makanan bergizi selama pandemic Covid-19. Tindakan seseorang dapat terwujud dalam suatu perilaku tidak sebatas adanya pengetahuan dan sikap yang baik. Hal ini dikarenakan perlu adanya niat dan norma subjektif untuk mendukung tindakan seseorang.

Berdasarkan hasil uji regresi logistik pada variabel sikap, untuk nilai koefisien B adalah 0,342 yang artinya bahwa jika skor rata-rata sikap meningkat satu satuan, maka skor rata-rata perilaku konsumsi makanan responden selama pandemic Covid-19 akan meningkat sebesar 0,342. Untuk nilai Sig diperoleh sebesar 0,076 ( Sig > 0,05), maka dapat disimpulkan bahwa tidak terdapat pengaruh sikap terhadap perilaku konsumsi makanan responden selama pandemic Covid-19. Pada variabel tindakan koefisien B yaitu 1,847 yang artinya jika skor rata-rata tindakan meningkat satu satuan, maka skor rata-rata perilaku konsumsi makanan responden selama pandemic Covid-19 akan meningkat sebesar 1,847 . Untuk nilai Sig diperoleh sebesar 0,000 (Sig > 0,05), maka dapat disimpulkan bahwa terdapat pengaruh tindakan terhadap perilaku konsumsi makanan responden selama pandemic Covid-19. Besarnya pengaruh ditunjukkan dengan nilai Exp (B) sebesar 6,339 yang bermakna responden dengan kategori tindakan cukup lebih cenderung mengalami perubahan perilaku konsumsi gizi yang cukup sebanyak 6,339 kali. Untuk nilai Chi Square diperoleh sebesar 0,000 yang bermakna secara bersama-sama sikap dan tindakan berpengaruh positif terhadap perilaku konsumsi makanan dan untuk nilai Nagelkerke $\mathrm{R}$ Square $\left(R^{2}\right)$ sebesar 0,215 yang artinya bahwa secara bersama-sama sikap dan tindakan memiliki pengaruh sebesar $21,5 \%$ terhadap perilaku konsumsi makanan responden selama pandemic Covid-19 sedangkan 78,5\% dipengaruhi oleh variabel lain. Hasil uji regresi dapat dilihat pada tabel berikut:

Tabel 4. Hasil uji regresi logistik

Variabel terikat: perilaku konsumsi makan selama pandemic Covid-19

\begin{tabular}{lccc}
\hline \multicolumn{1}{c}{ Variabel bebas } & Koef. B & $\operatorname{Exp~(B)~}$ & Sig \\
\hline Sikap (X2) & 0,342 & 1,408 & 0,076 \\
Tindakan (X3) & 1,847 & 6,339 & 0,000 \\
\hline Chi-square & & 0,000 \\
\hline Nagelkerke R Square & & 0,215 \\
\hline
\end{tabular}

Perubahan perilaku akan melalui proses, yaitu perubahan pengetahuan, sikap, kemudian praktik/tindakan. Beberapa penelitian telah membuktikan hal tersebut, tetapi penelitian lain 
membuktikan bahwa proses perubahan perilaku tidak selalu sejalan sesuai teori, bahkan di dalam praktik sehari-hari terjadi sebaliknya. Hal tersebut artinya bahwa meskipun seseorang telah memiliki pengetahuan yang cukup dan sikap positif namun tidak menjamin praktik/tindakannya akan positif juga. Bentuk perubahan perilaku antara lain perubahan alami, terencana, dan adanya kesediaan untuk berubah ${ }^{13}$. Dalam penelitian ini diketahui bahwa seseorang telah berpengetahuan dan bersikap positif, tetapi beberapa tindakannya masih kurang dalam mengonsumsi makanan bergizi. Setiap individu memiliki kesediaan berubah yang berbedabeda meski dengan kondisi yang sama ${ }^{6}$.

Menurut teori Bloom, stimulus yang diterima oleh subjek dapat langsung menimbulkan tindakan. Seseorang dapat bertindak atau menerapkan perilaku baru tanpa mengetahui terlebih dahulu makna stimulus yang diterimanya. Dengan kata lain tindakan seseorang tidak harus didasari oleh pengetahuan dan sikap ${ }^{6}$.

Faktor yang mempengaruhi pemilihan makanan dibagi menjadi tiga faktor yaitu faktor terkait makanan, faktor personal berkaitan dengan pengambilan keputusan pemilihan makanan, dan faktor sosial ekonomi. Anak telah memiliki urutan atribut produk yang penting dalam pembelian makanan. Atribut-atribut tersebut adalah rasa, harga, merek dan promosi ${ }^{15}$.

Banyak faktor yang mempengaruhi perilaku dalam konsumsi makanan, diantaranya pengetahuan yang kurang mengenai makanan dan gizi, sikap, persepsi tentang makanan, ketersediaan makanan dalam rumah tangga, kebiasaan makan, lingkungan fisik dan sosial, dan berbagai faktor lainnya. Sesungguhnya dengan perilaku konsumsi makanan yang baik dapat mencapai status gizi baik guna mencapai derajat kesehatan yang optimal ${ }^{16}$.

Penerapan pentingnya kebiasaan hidup sehat dan pola makan seimbang di dalam kehidupan sehari-hari belum dapat dirasakan oleh sebagian masyarakat. Olehnya itu, upaya perbaikan gizi tidak hanya dengan menyediakan sarana tetapi juga perlu upaya perbaikan pengetahuan, sikap dan praktik. Pendidikan gizi mempunyai manfaat yang besar dalam memberikan pengetahuan kepada masyarakat mengenai cara mengonsumsi makanan sesuai dengan konsep gizi seimbang ${ }^{17}$.

\section{SIMPULAN DAN SARAN}

Dari hasil penelitian, dapat disimpulkan bahwa pengetahuan tidak berhubungan dengan perilaku konsumsi makanan bergizi selama pandemic Covid-19 pada masyarakat Kabupaten Muna, karena walaupun masyakat memiliki pengetahuan cukup namun mereka tidak sepenuhnya dapat mewujudkan dalam tindakan nyata dengan mengonsumsi makanan yang bergizi. Untuk sikap mempunyai hubungan namun tidak mempunyai pengaruh terhadap perilaku konsumsi, dan untuk tindakan mempunyai hubungan signifikan serta pengaruh terhadap perilaku mengonsumsi makanan bergizi pada masyarakat Kabupaten Muna selama pandemic Covid-19.

Puskesmas sebagai fasilitas kesehatan tingkat pertama lebih berperan aktif dalam melaksanakan tindakan-tindakan pencegahan utamanya terhadap pencegahan penularan penyakit. Selain itu, masyarakat juga harus mau dan mampu dalam menjaga kesehatan perorangan salah satunya dengan mengonsumsi makanan yang sehat, bergizi dan beranekaragam agar dapat meningkatkan daya tahan tubuh sehingga dapat mencegah terjadinya penularan penyakit.

\section{DAFTAR PUSTAKA}

1. Buana, DR. (2020). Analisis perilaku masyarakat indonesia dalam menghadapi pandemi virus Corona (Covid-19) dan kiat menjaga kesejahteraan jiwa. SALAM J Sos dan Budaya Syar-i. 2020;7(3). doi:10.15408/sjsbs.v7i3.15082

2. Medika JM. Jurnal Menara Medika https://jurnal.umsb.ac.id/index.php/menaram edika/index JMM 2020 p-ISSN 2622-657X, eISSN 2723-6862. 2020;2(2):119-127. https://eresources.perpusnas.go.id:2125/media/public ations/326196-hubungan-pengetahuantentang-kesehatan-r-0e91516f.pdf

3. Kementerian Kesehatan R. final-panduan-giziseimbang-pada-masa-Covid-19-1.pdf.

https://covid19.go.id/storage/app/media/Mat eri\%20Edukasi/final-panduan-gizi-seimbangpada-masa-Covid-19-1.pdf. Published 2020. https://covid19.go.id/storage/app/media/Mat eri Edukasi/final-panduan-gizi-seimbang-padamasa-Covid-19-1.pdf

4. Purwonugroho, S., Nurheni, S.P., \& Nurjanah, S. (2018). Profil penanganan pangan, pola konsumsi dan status gizi keluarga : studi kasus di Kecamatan Kopo, Serang, Banten. J Mutu Pangan. 2018;5(1):34-42.

5. Khomsan, A. (2000). Teknik pengukuran pengetahuan gizi. Bogor: Institut Pertanian Bogor.

6. Notoatmodjo, S. (2003). Pendidikan dan perilaku kesehatan. Jakarta: PT. Rineka Cipta.

7. Asrina, T. (2013). Hubungan pengetahuan asupan gizi dengan status gizi siswa dan manajemen penyelenggaraan makan di SMA Negeri Tinggi Moncong Kabupaten Gowa 
Provinsi Sulawesi Selatan. J Media Gizi. 2013;2(2):90-97.

8. Tarawan, V.M., Lesmana, R., Gunawan, H., \& Gunadi, J.W. (2020). Hubungan antara pola konsumsi dan tingkat pengetahuan mengenai gizi seimbang pada warga Desa Clmenyan. J Pengabdi Kpd Masy. 2020;4(2):129-132.

9. Maharibe, C.C. (2014). Hubungan pengetahuan gizi seimbang dengan praktik gizi seimbang mahasiswa Program Studi Pendidikan Dokter Angkatan 2013 Fakultas Kedokteran Universitas Sam Ratulangi. J e-Biomedik. 2014;2(1). doi:10.35790/ebm.2.1.2014.3711

10. Saifuddin, A. (2005). Sikap manusia teori dan pengukurannya. Pustaka Pelahar.

11. Shaluhiyah, Z., Kusumawati, A., Indraswari, R., Widjanarko, B., \& Husodo, B.T. (2020). Pengetahuan, sikap dan praktik ibu dalam pemberian makanan sehat keluarga di Kota Semarang. J Gizi Indones (The Indones J Nutr. 2020;8(2):92-101. doi:10.14710/jgi.8.2.92-101

12. Sediaoetama, A. (2000). IImu gizi untuk mahasiswa dan profesi. Dian Rakyat.

13. Agustin, F., Fayasari, A., \& Dewi, G.K. (2018). Pengetahuan, sikap, dan perilaku gizi seimbang terhadap status gizi lebih pada pegawai Rumah Sakit Penyakit Infeksi Sulianti Saroso Jakarta Utara. IImu Gizi Indones. 2018;1(2):93. doi:10.35842/ilgi.v1i2.19

14. Fadhilah, F.H., Widjanarko, B., \& Shaluhiyah, Z., (2018). Pendidikan B, Perilaku I. Faktor-faktor yang berhubungan dengan perilaku makan pada anak gizi lebih di sekolah menengah pertama wilayah kerja Puskesmas Poncol Kota Semarang. J Kesehat Masy. 2018;6(1):734-744.

15. Syam, A., Indriasari, R., \& In, I. (2018). Gambaran pengetahuan dan sikap siswa terhadap makanan jajanan sebelum dan setelah pemberian edukasi kartu kwartet pada anak usia sekolah dasar di Kota Makassar. J TEPAT. 2018;1(2):127-136.

16. Wayan, N, Witari, S., Dewa, I., et al. Perilaku konsumsi gizi seimbang mahasiswa Jurusan Gizi Politeknik Kesehatan Denpasar:75-89.

17. Sholehah, S. 済無No Title No Title. $D k$. 2014;53(9):1689-1699.

doi:10.1017/CBO9781107415324.004 